\title{
Electrochemical Imaging for Single-cell Analysis of Cell Adhesion Using a Collagen-coated Large-scale Integration (LSI)-based Amperometric Device
}

\section{Hiroya ABE, ${ }^{a}$ Yusuke KANNO, ${ }^{a}$ Kosuke INO, $^{a, *}$ Kumi Y. INOUE, ${ }^{a}$ Atsushi SUDA, ${ }^{b}$ Ryota KUNIKATA, ${ }^{b}$ Masahki MATSUDAIRA, ${ }^{c}$ Hitoshi SHIKU, ${ }^{a}$ and Tomokazu MATSUE ${ }^{a, d,} *$}

a Graduate School of Environmental Studies, Tohoku University, 6-6-11-604 Aramaki-aza Aoba, Aoba-ku, Sendai 980-8579, Japan

b Japan Aviation Electronics Industry, Ltd., 1-1 Musashino 3-chome, Akishima, Tokyo, 196-8555, Japan

c Micro System Integration Center, Tohoku University,

519-1176 Aramaki-aza Aoba, Aoba-ku, Sendai 980-0845, Japan

d WPI-Advanced Institute for Materials Research, Tohoku University,

2-1-1-509 Katahira, Aoba-ku, Sendai 980-8577, Japan

*Corresponding authors: ino.kosuke@bioinfo.che.tohoku.ac.jp, matsue@bioinfo.che.tohoku.ac.jp

\begin{abstract}
We here report the electrochemical imaging of cell adhesion using a large-scale integration (LSI)-based amperometric device, called a Bio-LSI device. The device consists of 400 sensor electrodes arranged with a pitch of $250 \mu \mathrm{m}$. The device surface was modified with collagen to assist in the culture of MCF-7 cells and promote their adhesion. The cells disturb the electrochemical reaction of redox mediators, allowing the electrochemical signal to be used to evaluate cell adhesion at the single-cell level. This approach was applied to a cell detachment test. The results show that the Bio-LSI device is a promising tool for single-cell analysis.
\end{abstract}

(C) The Electrochemical Society of Japan, All rights reserved.

Keywords : Electrochemical Imaging, LSI-based Amperometric Device, Single-cell Analysis, Cell Adhesion

\section{Introduction}

Cell assays, and particularly single-cell analyses, are important for medical and engineering applications. Cell adhesion is a fundamental cellular function; for example, more than $70 \%$ of malignant tumors are of epithelial origin. ${ }^{1}$ Therefore, an understanding of cell adhesion would have far-reaching implications in the biological sciences and in medicine.

Several diverse methods have been developed for single-cell analysis, of which electrochemical sensors are a powerful tool as they are inexpensive, suitable for miniaturization and microfabrication, and allow real-time and quantitative analysis. Microelectrodes have been widely used for single-cell analysis, ${ }^{2}$ such as of exocytosis ${ }^{3}$ and respiration activity. ${ }^{4}$ Microelectrode arrays have been designed and used for parallel analyses of single cells. ${ }^{5}$ For example, an electrode-array device consisting of microwells was fabricated to trap single cells and detect exocytosis ${ }^{6}$ and cellular enzymatic activity. ${ }^{7} \mathrm{Kim}$ et al. recently reported a complementary metal oxide semiconductor (CMOS)-based electrode array containing 100 electrodes for the simultaneous recording of exocytotic events from cells. ${ }^{8}$

We previously developed a Bio-LSI (large-scale integration) device for the characterization of biomaterials that comprises 400 electrochemical sensors with a pitch of $250 \mu \mathrm{m}$ arranged to form a LSI-based amperometric device. ${ }^{9-14}$ The device is based on CMOS technology and an operational amplifier is incorporated into each sensor. The amplifier consists of a switched-capacitor type $I-V$ converter to amplify the in-pixel signal for amperometric detection. ${ }^{10,11}$ The device has been used for the electrochemical imaging of alkaline phosphatase in embryonic stem (ES) cells, ${ }^{13} \alpha$-actinin in differentiated ES cells, ${ }^{14}$ and neurotransmitters from PC12 cells. ${ }^{9}$

In the present study, the Bio-LSI device was used for the electrochemical imaging of cell adhesion at the single-cell level by monitoring the electrochemical reaction between two redox mediators, $\left[\mathrm{Fe}(\mathrm{CN})_{6}\right]^{4-}$ and ferrocenemethanol $\left(\mathrm{FcCH}_{2} \mathrm{OH}\right)$. In addition, cell detachment was evaluated by monitoring cell adhesion. The results show that the Bio-LSI device is a useful tool for high throughput single-cell analyses based on cell adhesion measurements.

\section{Experimental}

\subsection{Device fabrication}

The fabrication process was previously described. ${ }^{11}$ An LSI chip was designed by Toppan Technical Design Center Co., Ltd. (Japan), manufactured by SMIC (China), and modified for electrochemical measurements. Briefly, Au electrodes as sensors were prepared on Al pads using lift-off lithography. SU-8 (SU-8 3005, MicroChem, USA) microwells (diameter: $40 \mu \mathrm{m}$; depth: approximately $5 \mu \mathrm{m}$ ) were fabricated on the electrodes (Fig. 1). The chip was attached on a ceramic substrate containing connector pads (Japan Aviation

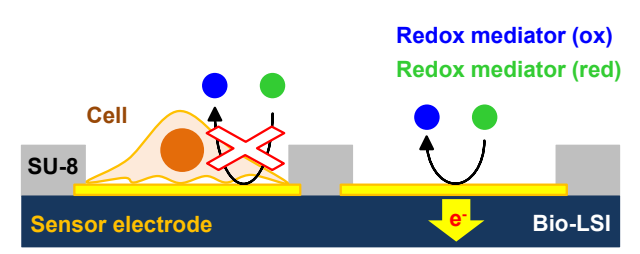

Figure 1. (Color online) Scheme for detecting cell adhesion. Cells are cultured on a collagen-coated device. Following cell adhesion, the culture medium is exchanged for a solution containing redox mediators, and the mediators are oxidized at the sensors. Cells adhering on the sensors block the electrochemical reaction, leading to a reduction in the current signal. 
Electronics Industry, Ltd., Japan) using Ag paste, then the chip was connected to the substrate using HB16 wire bonder and a motorized Z- \& Y-Axis (TPT Japan Co., Ltd., Japan) to complete the device. A polycarbonate reservoir (Japan Aviation Electronics Industry, Ltd.) was then bonded onto the device to insulate the connector electrodes and to hold the sample solutions.

\subsection{Collagen coating and cell culture on the device}

MCF-7 cells are widely used as a cancer model for studying characteristics related to cell metastasis, such as cell adhesion, and so were used in this study; the cells were kindly donated by the Institute of Development, Aging and Cancer, Tohoku University. Collagen (Cellmatrix type 1-C, Nitta Gelatin Inc., Japan) was coated on the device surface according to the protocol from the manufacturer. RPMI 1640 (1 mL; Gibco, USA) supplemented with $10 \%$ fetal bovine serum (Gibco) and $1 \%$ penicillin/streptomycin was introduced onto the device, and a $10 \mu \mathrm{L}$ suspension of MCF-7 cells (approximately $5 \times 10^{7}$ cells) was deposited in the center of the sensor area. The device was gently transferred to an incubator and the cells were cultured at $37^{\circ} \mathrm{C}$ under a $5 \% \mathrm{CO}_{2}$ atmosphere for $12 \mathrm{~h}$. The cells on the device were observed under a microscope (VHX1000 , Keyence, Japan) and optical images of the cells on each sensor electrode were acquired.

\subsection{Electrochemical characterization of the collagen-coated device}

The effects of collagen modification on electrochemical signals were determined by measuring the redox mediators $\left[\mathrm{Fe}(\mathrm{CN})_{6}\right]^{4-}$ and $\mathrm{FcCH}_{2} \mathrm{OH}$ before and after the modification. A phosphate buffered saline (PBS) solution (Wako Pure Chemical Industries, Ltd., catalog no. 041-20211) containing $0-2.0 \mathrm{mM} \mathrm{K}_{4}\left[\mathrm{Fe}(\mathrm{CN})_{6}\right]$ or $1.0 \mathrm{mM} \mathrm{FcCH}_{2} \mathrm{OH}$ was introduced onto the device and the reference $(\mathrm{Ag} / \mathrm{AgCl} /$ sat. $\mathrm{KCl})$ and $\mathrm{Pt}$ counter electrodes were inserted into the solution. Cyclic voltammetry and amperometry were performed to acquire the oxidation currents of $\left[\mathrm{Fe}(\mathrm{CN})_{6}\right]^{4-}$ or $\mathrm{FcCH}_{2} \mathrm{OH}$. The working electrodes were stepped from 0.00 to $0.50 \mathrm{~V}$ to oxidize the mediators for the amperometric measurements. Electrochemical signals from each electrode were recorded every $200 \mathrm{~ms}$. Potential stepping and data acquisition were performed using a Bio-LSI control system. ${ }^{11}$

\subsection{Electrochemical imaging of cell adhesion and cell detachment}

A general outline of the detection strategy is shown in Fig. 1. Following cell culture, the culture medium was exchanged for a PBS solution containing $1.0 \mathrm{mM} \mathrm{K}_{4}\left[\mathrm{Fe}(\mathrm{CN})_{6}\right]$. $\left[\mathrm{Fe}(\mathrm{CN})_{6}\right]^{4-}$ was oxidized on each sensor electrode at $0.50 \mathrm{~V}$ to obtain electrochemical images, then the solution was exchanged for a PBS solution containing $1.0 \mathrm{mM} \mathrm{FcCH} \mathrm{F}_{2} \mathrm{OH}$ and $\mathrm{FcCH}_{2} \mathrm{OH}$ was oxidized on each sensor electrode at $0.50 \mathrm{~V}$. Cell detachment was assayed by exchanging the solution for a PBS solution containing $0.1 \%$ Triton X-100 (SigmaAldrich Japan, Japan), thus inducing cells detachment from the electrodes. The solution was then exchanged for a PBS solution containing $1.0 \mathrm{mM} \mathrm{K}_{4}\left[\mathrm{Fe}(\mathrm{CN})_{6}\right]$, and electrochemical imaging was performed as described above.

\section{Results and Discussion}

\subsection{Electrochemical characterization of the collagen-coated device}

The collagen-coated device was characterized by cyclic voltammetry and chronoamperometry. Figure $2 \mathrm{~A}$ shows the cyclic voltammograms of $1.0 \mathrm{mM}\left[\mathrm{Fe}(\mathrm{CN})_{6}\right]^{4-}$ before and after the collagen modification. The averages of the currents from the 400 bare electrodes and the 400 collagen-modified electrodes were $4.73 \pm 0.17$ and $4.15 \pm 0.22 \mathrm{nA}$, respectively, at $0.60 \mathrm{~V}$. The
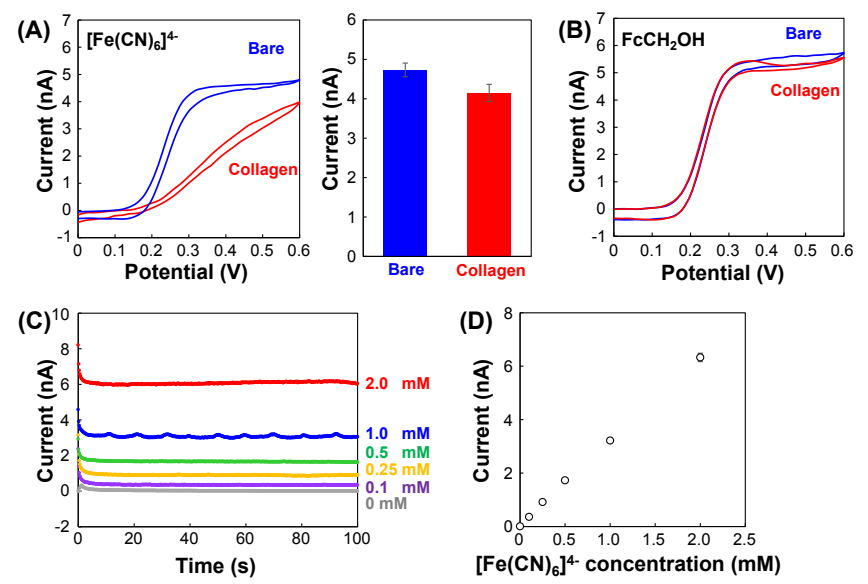

Figure 2. (Color online) Characterization of a collagen-coated device. Cyclic voltammograms for $1.0 \mathrm{mM}\left[\mathrm{Fe}(\mathrm{CN})_{6}\right]^{4-}$ (A) or $1.0 \mathrm{mM} \mathrm{FcCH}_{2} \mathrm{OH}$ (B) at bare (blue) and collagen-coated (red) $\mathrm{Au}$ electrodes. Scan rate: $100 \mathrm{mV} / \mathrm{s}$. The averages and standard deviations of the $\mathrm{CV}\left[\mathrm{Fe}(\mathrm{CN})_{6}\right]^{4-}$ currents at $0.60 \mathrm{~V}$ are plotted on graph (A). (C) Chronoamperograms for $0-2.0 \mathrm{mM}\left[\mathrm{Fe}(\mathrm{CN})_{6}\right]^{4-}$ using the collagen-coated device. The potential was stepped from 0.00 to $0.50 \mathrm{~V}$ at $0 \mathrm{~s}$. (D) Calibration curve of $\left[\mathrm{Fe}(\mathrm{CN})_{6}\right]^{4-} 100 \mathrm{~s}$ after the potential step. The collagen-coated device was used for the calibration curve.

standard deviations for both conditions were small, indicating that the collagen was coated uniformly on the device. The theoretical current of a single microdisk electrode in a microwell was calculated using the following formula: ${ }^{.15}$

$$
i=\frac{4 \pi n F C D r^{2}}{4 L+\pi r}
$$

where $i$ is the value of the current, $n$ is the number of electrons exchanged, $F$ is the Faraday constant, $C$ is the analyte concentration, $D$ is the diffusion coefficient $\left(\left[\mathrm{Fe}(\mathrm{CN})_{6}\right]^{4-}: 7.6 \times 10^{-10} \mathrm{~m}^{2} / \mathrm{s}\right),{ }^{16} r$ is the electrode radius, and $L$ is the depth of the microwell. The theoretical value was $4.45 \mathrm{nA}$, which is similar to the experimental results before the modification.

Collagen modification impeded the oxidation of $\left[\mathrm{Fe}(\mathrm{CN})_{6}\right]^{4-}$, whereas no effect was observed on the oxidation currents of $\mathrm{FcCH}_{2} \mathrm{OH}$ (Figs. 2A and 2B). These findings indicate that collagen modification blocks the active sites for electron-transfer at the electrode surfaces and largely influences the oxidation of $\left[\mathrm{Fe}(\mathrm{CN})_{6}\right]^{4-}$, which intrinsically shows slow electron-transfer. However, the response at $0.50 \mathrm{~V}$ following collagen modification is only slightly decreased and shows steady-state responses in chronoapmerometry (Fig. 2C); therefore, we used the response at $0.50 \mathrm{~V}$ to evaluate cell adhesion. Figure 2D shows a calibration curve of $\left[\mathrm{Fe}(\mathrm{CN})_{6}\right]^{4-}$ at the collagen-coated electrodes, indicating that quantitative analysis can be performed.

\subsection{Electrochemical imaging of cell adhesion}

The optical images shown in Fig. 3A indicate that MCF-7 cells adhered on the device after 12 hours of culture and that one or several cells were present in many of the $40-\mu \mathrm{m}$ diameter microwells (Fig. 3A). The number of cells in the microwells was classified into four categories: no cells, one cell, two cells, and three or more cells, and a 2D image was constructed for this categorization (Fig. 3B).

Figure $3 \mathrm{C}$ shows the relationship between the oxidation currents of $\left[\mathrm{Fe}(\mathrm{CN})_{6}\right]^{4-}$ and the number of cells in the microwells. The oxidation current of $1.0 \mathrm{mM}\left[\mathrm{Fe}(\mathrm{CN})_{6}\right]^{4-}$ from sensors in microwells without cells was $2.01 \pm 0.19 \mathrm{nA}$. This is lower than the current 

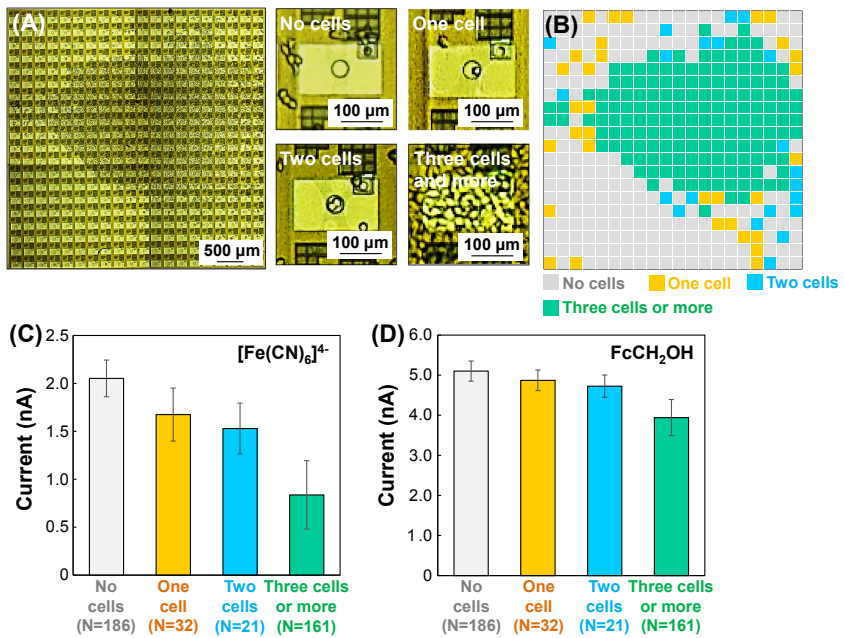

Figure 3. (Color online) Electrochemical imaging of cell adhesion. (A) Optical images of cells on the device after 12 hours of culture. The number of cells was counted to categorize the sensors as follows: no cells, one cell, two cells, and three or more cells. (B) The categorization is depicted as a 2D image. (C) Electrochemical imaging using $\left[\mathrm{Fe}(\mathrm{CN})_{6}\right]^{4-}$. The oxidation currents of $\left[\mathrm{Fe}(\mathrm{CN})_{6}\right]^{4-}$ $120 \mathrm{~s}$ after the potential step are plotted on the graph. (D) Electrochemical imaging using $\mathrm{FcCH}_{2} \mathrm{OH}$. The oxidation currents of $\mathrm{FcCH}_{2} \mathrm{OH} 120 \mathrm{~s}$ after the potential step are plotted on the graph.

before culturing the cells and indicates that components of the culture medium adsorbed onto the electrode surfaces during culture, impeding the electrochemical reaction. When a single cell was trapped in the microwells, the oxidation current of $\left[\mathrm{Fe}(\mathrm{CN})_{6}\right]^{4-}$ was further reduced (Fig. 3C). There was a significant difference between microwells containing no cells and microwells containing a single cell, indicating that single-cell analysis was successfully performed. As the number of cells in the microwells increased, the current gradually decreased (one cell: $1.68 \pm 0.28 \mathrm{nA}$; two cells: $1.53 \pm 0.27 \mathrm{nA}$; three or more cells: $0.84 \pm 0.36 \mathrm{nA}$ ). Despite the lower current from wells containing two trapped cells compared to wells containing one trapped cell, the difference was not statistically significant. The small current blocking effect caused by two cells may be lower than expected due to cellar interactions between the two cells. Regardless, these results show that the Bio-LSI device can be used to evaluate cell adhesion at the single-cell level.

Figure 3D shows the relationship between the oxidation current of $1.0 \mathrm{mM} \mathrm{FcCH} \mathrm{m}_{2} \mathrm{OH}$ and the number of cells in the microwells. Although the adsorption of components of the medium also affected the oxidation current, the effect was less pronounced than for $\left[\mathrm{Fe}(\mathrm{CN})_{6}\right]^{4-}$. In addition, the reduction in signal intensity due to cell adhesion was also lower as compared to $\left[\mathrm{Fe}(\mathrm{CN})_{6}\right]^{4-}$ because $\mathrm{FcCH}_{2} \mathrm{OH}$ is a hydrophobic mediator and can permeate cells. Thus, the physico-chemical properties of the mediator affect its permeation of the cell membrane. $\left[\mathrm{Fe}(\mathrm{CN})_{6}\right]^{4-}$ is known to not cross the cell membrane due to the membrane's negative charge. Consequently, the larger changes in signal intensity obtained using $\left[\mathrm{Fe}(\mathrm{CN})_{6}\right]^{4-}$ compared to $\mathrm{FcCH}_{2} \mathrm{OH}$ indicate that $\left[\mathrm{Fe}(\mathrm{CN})_{6}\right]^{4-}$ is the better mediator for evaluating cell adhesion.

Although the cells were successfully cultured on the device for 3 days, the device gave unstable electrochemical signals after 3 days of culture. Therefore, measurements should be conducted after less than 3 days of culture.

Although an optical microscope can be used to observe the shapes of cells, it is difficult to observe cell adhesion visually. In contrast, the present method can detect cell adhesion because the electrochemical signals were affected by the electrode surface.
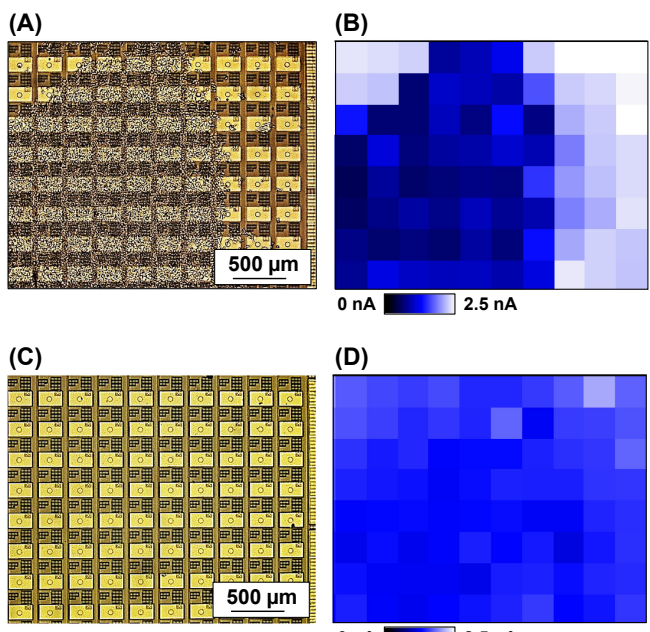

(D)

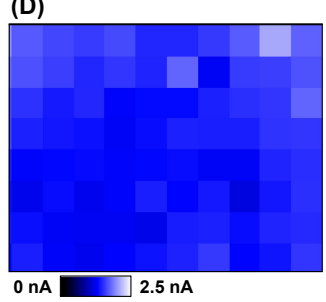

Figure 4. (Color online) Electrochemical imaging of cell detachment using $\left[\mathrm{Fe}(\mathrm{CN})_{6}\right]^{4-}$. The optical and electrochemical images before (A and $\mathrm{B})$ and after $(\mathrm{C}$ and $\mathrm{D})$ detachment of the cells with $0.1 \%$ Triton X-100. The electrochemical images consist of $8 \times 10$ electrochemical signals acquired $120 \mathrm{~s}$ after the potential step from 0.00 to $0.50 \mathrm{~V}$.

Although cell adhesion was not examined in detail in the present study, we believe that this method is useful for the detection of cell adhesion at the single-cell level.

\subsection{Evaluation of cell detachment at the single-cell level by electrochemical imaging}

Preliminary experiments to evaluate the detection of cell detachment were performed using Triton X-100, a non-ionic surfactant that lyses cells, as a toxic chemical. ${ }^{17}$ Figures $4 \mathrm{~A}$ and $4 \mathrm{~B}$ show optical and electrochemical images, respectively, of the cells before treatment with Triton X-100. Approximately $10 \mathrm{~min}$ of treatment with Triton X-100 resulted in almost complete detachment of the cells from the device surface (Fig. 4C) and a change in the oxidation current of $\left[\mathrm{Fe}(\mathrm{CN})_{6}\right]^{4-}$ from approximately 0.9 to $1.4 \mathrm{nA}$ (Fig. 4D). These results show that changes in cell adhesion can be evaluated from changes in the electrochemical signals. However, the currents did not recover completely following removal of the Triton X-100, probably due to fouling of the electrode surfaces by the surfactant. Nonetheless, the results demonstrate that electrochemical detection can be used to evaluate cell detachment at the single-cell level.

Nakazato and coworkers recently reported CMOS-based electrochemical devices for the direct enumeration of HeLa cells via the blocking effect of $\left[\mathrm{Fe}(\mathrm{CN})_{6}\right]^{4-} .{ }^{18} \mathrm{HeLa}$ cells were cultured on a device for 2 hours and the blocking of the mediator was monitored. The aim of the present study was to show the applicability of the Bio-LSI for monitoring a conventional cell culture system using collagen modification. The results demonstrate that this device can be used to monitor the status of a culture and for testing various compounds contributing to cell detachment.

\section{Conclusions}

The present study demonstrated the applicability of the Bio-LSI device for detecting cell adhesion: cell adhesion on the sensors blocks the electrochemical oxidation of $\left[\mathrm{Fe}(\mathrm{CN})_{6}\right]^{4-}$ and $\mathrm{FcCH}_{2} \mathrm{OH}$, thus reducing the oxidation signal at the sensors in a manner dependent on the number of cells in the sensor microwell. The device can be used to evaluate cell adhesion at the single-cell level, and can also be used for a cell detachment test. The detection system can be applied to other adhesion cells. The Bio-LSI is therefore useful for drug screening by evaluating cell adhesion. 


\section{Acknowledgments}

This work was supported in part by a Grant-in-Aid for Scientific Research (A) (No. 25248032), a Grant-in-Aid for Young Scientists (A) (No. 15H05415) and a Grant-in-Aid for Challenging Exploratory Research (No. 26600057) from the Japan Society for the Promotion of Science (JSPS). This work was also supported by Special Coordination Funds for Promoting Science and Technology, Creation of Innovation Centers for Advanced Interdisciplinary Research Areas Program from the Japan Science and Technology Agency. In addition, this work was also supported by the Asahi Glass Foundation, as well as by a Grant-in-Aid from the Tohoku University Institute for International Advanced Research and Education.

\section{References}

1. B. E. Henderson, R. K. Ross, and M. C. Pike, Science, 254, 1131 (1991); Z. Lin, K. Ino, H. Shiku, and T. Matsue, Chem. Commun., 46, 559 (2010).

2. R. Trouillon, M. K. Passarelli, J. Wang, M. E. Kurczy, and A. G. Ewing, Anal. Chem., 85, 522 (2013).

3. J. Yao and K. D. Gillis, Analyst, 137, 2674 (2012).

4. T. Yasukawa, Y. Kondo, I. Uchida, and T. Matsue, Chem. Lett., 8, 767 (1998).

5. J. Wang and A. G. Ewing, Analyst, 139, 3290 (2014).

6. X. Liu, S. Barizuddin, W. Shin, C. J. Mathai, S. Gangopadhyay, and K. D. Gillis,
Anal. Chem., 83, 2445 (2011).

7. M. Sen, K. Ino, H. Shiku, and T. Matsue, Biotechnol. Bioeng., 109, 2163 (2012); M. Sen, K. Ino, H. Shiku, and T. Matsue, Lab Chip, 12, 4328 (2012)

8. B. N. Kim, A. D. Herbst, S. J. Kim, B. A. Minch, and M. Lindau, Biosens. Bioelectron., 41, 736 (2013).

9. H. Abe, K. Ino, C. Z. Li, Y. Kanno, K. Y. Inoue, A. Suda, R. Kunikata, M. Matsudaira, Y. Takahashi, H. Shiku, and T. Matsue, Anal. Chem., 87, 6364 (2015).

10. K. Y. Inoue, M. Matsudaira, R. Kubo, M. Nakano, S. Yoshida, S. Matsuzaki, A Suda, R. Kunikata, T. Kimura, R. Tsurumi, T. Shioya, K. Ino, H. Shiku, S. Satoh, M. Esashi, and T. Matsue, Lab Chip, 12, 3481 (2012).

11. K. Y. Inoue, M. Matsudaira, M. Nakano, K. Ino, C. Sakamoto, Y. Kanno, R. Kubo, R. Kunikata, A. Kira, A. Suda, R. Tsurumi, T. Shioya, S. Yoshida, M. Muroyama, T. Ishikawa, H. Shiku, S. Satoh, M. Esashi, and T. Matsue, Lab Chip, 15, 848 (2015).

12. Y. Kanno, K. Ino, K. Y. Inoue, M. Sen, A. Suda, R. Kunikata, M. Matsudaira, H. Abe, C. Z. Li, H. Shiku, and T. Matsue, J. Electroanal. Chem., 741, 109 (2015); Y. Kanno, K. Ino, K. Y. Inoue, A. Suda, R. Kunikata, M. Matsudaira, H. Shiku, and T. Matsue, Anal. Sci., 31, 715 (2015)

13. M. Sen, K. Ino, K. Y. Inoue, T. Arai, T. Nishijo, A. Suda, R. Kunikata, H. Shiku, and T. Matsue, Biosens. Bioelectron., 48, 12 (2013).

14. M. Sen, K. Ino, K. Y. Inoue, A. Suda, R. Kunikata, M. Matsudaira, H. Shiku, and T. Matsue, Anal. Methods, 6, 6337 (2014)

15. J. Wang, R. Trouillon, Y. Lin, M. I. Svensson, and A. G. Ewing, Anal. Chem., 85, 5600 (2013).

16. J. Yang and S. Gunasekaran, Carbon, 51, 36 (2013).

17. D. Koley and A. J. Bard, Proc. Natl. Acad. Sci. U.S.A., 107, 16783 (2010).

18. S. Ota, K. Niitsu, H. Kondo, M. Hori, and K. Nakazato, Biomedical Circuits and Systems Conference (BioCAS), 2014 IEEE, p. 460 (2014). 